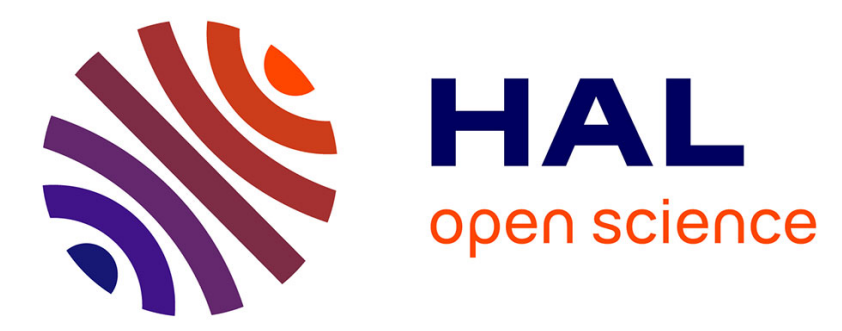

\title{
Exponential population increase in the endangered Ouvéa Parakeet () after community-based protection from nest poaching
}

Nicolas Barré, Jörn Theuerkauf, Ludovic Verfaille, Pierre Primot, Maurice Saoumoé

\section{To cite this version:}

Nicolas Barré, Jörn Theuerkauf, Ludovic Verfaille, Pierre Primot, Maurice Saoumoé. Exponential population increase in the endangered Ouvéa Parakeet () after community-based protection from nest poaching. Journal für Ornithologie = Journal of Ornithology, 2010, 151 (3), pp.695-701. 10.1007/s10336-010-0499-7 . hal-00574835

\section{HAL Id: hal-00574835 \\ https://hal.science/hal-00574835}

Submitted on 9 Mar 2011

HAL is a multi-disciplinary open access archive for the deposit and dissemination of scientific research documents, whether they are published or not. The documents may come from teaching and research institutions in France or abroad, or from public or private research centers.
L'archive ouverte pluridisciplinaire HAL, est destinée au dépôt et à la diffusion de documents scientifiques de niveau recherche, publiés ou non, émanant des établissements d'enseignement et de recherche français ou étrangers, des laboratoires publics ou privés. 


\title{
Exponential population increase in the endangered Ouvéa Parakeet (Eunymphicus uvaeensis) after community-based protection from nest poaching
}

\author{
Nicolas Barré • Jörn Theuerkauf $\cdot$ Ludovic Verfaille • \\ Pierre Primot $\cdot$ Maurice Saoumoé
}

Received: 20 July 2009/Revised: 16 January 2010/Accepted: 1 February 2010/Published online: 9 March 2010

(C) Dt. Ornithologen-Gesellschaft e.V. 2010

\begin{abstract}
The Ouvéa Parakeet (Eunymphicus uvaeensis), endemic to Ouvéa Island (Loyalty Islands, New Caledonia, south-west Pacific), is a rainforest bird that is dependent on tree cavities for nesting. It is threatened by deforestation, but also by competition for nest sites with introduced bees, harvesting for pets, and potentially predation by introduced species. Despite these threats, we show that the Ouvéa Parakeet population increased exponentially from an estimated 617 (274-996) birds in 1993 to 2,090 $(1,280-3,413)$ birds in 2009 (95\% confidence interval). We explain this population increase by community-based protection measures that eliminated nest poaching. We recommend that these measures are maintained, remnant forest is protected, and the introduction of rats is prevented.
\end{abstract}

Keywords Nest poaching P Public awareness ·

Recovery plan · Threats

Communicated by T. Friedl.

N. Barré

SCO/IAC-CIRAD, BP 3135, 98846 Nouméa, New Caledonia

e-mail: belairbarre@hotmail.fr

J. Theuerkauf $(\square)$

Museum and Institute of Zoology, Polish Academy of Sciences, Wilcza 64, 00-679 Warsaw, Poland

e-mail: jtheuer@miiz.waw.pl

L. Verfaille · P. Primot · M. Saoumoé

Direction du Développement Economique, Province des Iles

Loyauté, BP 50, 98820 Wé, Lifou, New Caledonia

e-mail: verfaille@loyalty.nc

P. Primot

e-mail: p.primot@oie.int

M. Saoumoé

e-mail: m-saoumoe@loyalty.nc

\section{Introduction}

The Ouvéa Parakeet (Eunymphicus uvaeensis) is endemic to the small island of Ouvéa (Loyalty Islands, New Caledonia, south-west Pacific). The species was previously considered a subspecies of the Horned Parakeet (Eunymphicus cornutus), which is endemic to mainland New Caledonia (Grande Terre). The Ouvéa Parakeet is now recognized as a full species (Juniper and Parr 1998; Boon et al. 2008). The two species are the only taxa of the genus Eunymphicus.

The Ouvéa Parakeet is a rainforest species that nests in cavities in mature trees (Robinet et al. 1996; Robinet and Salas 1996), and is consequently highly susceptible to deforestation and selective harvesting of large trees. It mainly feeds in forest, but also in fruit and vegetable gardens, and young secondary forests. Population estimates in the 1980s and early 1990s varied from less than 200 individuals (King 1981; Lambert et al. 1992) to between 70 and 90 individuals (Hahn 1993). The entire population was presumed to be restricted to $20 \mathrm{~km}^{2}$ of forest in the northern part of the island (Hannecart 1988). In 1963, a translocation of 15 parakeets to the adjacent island of Lifou failed to establish a second population (Bruce 1978; Hannecart 1988). In 1993, the first comprehensive census estimated the population at about 620 birds, most occurring in the north of Ouvéa, but also a few in the south (Robinet et al. 1996).

Based on its small population, its limited range on just one island, the decrease of suitable habitat as a result of coconut plantations, and the impact of human harvest, the Ouvéa Parakeet was categorised as Vulnerable in 1994 (Collar et al. 1994) and upgraded to Endangered in 2000 (BirdLife International 2009). It is legally protected from trade by New Caledonian law, and in 2000, the genus 
Eunymphicus was transferred from Appendix II of CITES (since 1975) to Appendix I (UNEP-WCMC 2009).

Despite protection by local law since 1935 (Hannecart 1988), the species was a favoured pet and has been captured (by snaring or nest poaching without destroying the nest cavity) and exported from the island for over a century (Sarasin 1913; Berlioz 1945). The impact of this harvesting was dependent on external demands and is thought to have increased in the second half of the twentieth century, with 30-50 young taken each year (Robinet et al. 1995). This harvest rate might have been close to the species' total annual reproductive output, and was probably unsustainable (Robinet et al. 1996).

Besides collection for pets and trade, there are several other potential threats to the survival and increase of the population: (1) the Little Fire Ant (Wasmannia auropunctata), which can severely impact biodiversity (Jourdan 1997), was introduced to Ouvéa in the early 1990s; (2) the Honey Bee (Apis mellifera ligustica), which competes with the parakeets for tree cavities, was introduced to Ouvéa in 1994, and by 2005, there were at least 250 colonies throughout the island (Taylor 2005); (3) the New Caledonian Rainbow Lorikeet (Trichoglossus haematodus deplanchii), a potential nest-cavity competitor, was introduced from Grande Terre in the 1970s; and (4) a range of species prey upon the Ouvéa Parakeet (Robinet et al. 1996), both natural (Brown Goshawk Accipiter fasciatus and Pacific Boa Candoia bibroni) and introduced (Feral Cat Felis catus). Another potential predator, the Black Rat (Rattus rattus), was introduced to Grande Terre and the other Loyalty Islands, but not to Ouvéa (Robinet and Salas 1996).

In an effort to save the Ouvéa Parakeet, the ASPO (Association for the Protection of the Ouvéa Parakeet) was created in 1993. The ASPO was established as a nongovernmental organisation of mostly local members to ensure that its proposed conservation measures were accepted by the Ouvéan community. The ASPO initiated a long-term study of the biology and ecology of the species (Robinet 1997) as a basis for two recovery plans (19972002 and 2003-2008) that were prepared with Ouvéan inhabitants, and accepted by local authorities and the Loyalty Islands administration (ASPO 2003; Anonymous 2004). The recovery plans recommended increasing law enforcement to tackle illegal trade, mitigating habitat degradation and restoring suitable habitat, monitoring nesting sites, testing artificial nests, preventing the introduction of Black Rats, locating and destroying Honey Bee nests in the wild, and improving public awareness of the value of the Ouvéa Parakeet.

In order to meet the recommendations formulated by the Species Survival Commission of the IUCN (Lambert et al. 1992), the South Pacific Regional Bird Conservation
Programme Plan for Action (Sherley 2000), and the priorities defined in the two recovery plans, a population monitoring programme was established in 1993 to evaluate the efficacy of the conservation management programme. In this paper, we present the results of eight censuses of the Ouvéa Parakeet conducted over 16 years, and discuss the reasons for the observed population trend.

\section{Methods}

Ouvéa lies $100 \mathrm{~km}$ north-east of Grande Terre $\left(20^{\circ} 23\right.$ $44^{\prime} \mathrm{S}, 166^{\circ} 25-40^{\prime} \mathrm{E}$ ), and forms part of the Loyalty Island archipelago. The island is relatively small $\left(130 \mathrm{~km}^{2}\right)$, and flat (max. elevation $41 \mathrm{~m}$ ), and is inhabited by 5,100 people, mostly of Melanesian and Polynesian origin. Ouvéa receives an average annual rainfall of $1,250 \mathrm{~mm}$, and is mainly covered by tropical rainforest on coral substrates (Fig. 1). Ouvéa is described in detail by Robinet et al. (1995). The entire island has recently been classified as an Important Bird Area (Spaggiari et al. 2007). Besides recovery plan meetings, the ASPO organises community work through regular discussions with inhabitants of Ouvéa, to explain the aims and activities of the association by various means of communication (including fact sheets, stickers, leaflets, posters, a newsletter, T-shirts, radio and TV spots, and films). In 1993, the ASPO employed three local guides from villages all over the island to spread conservation messages and to protect parakeet nests in the

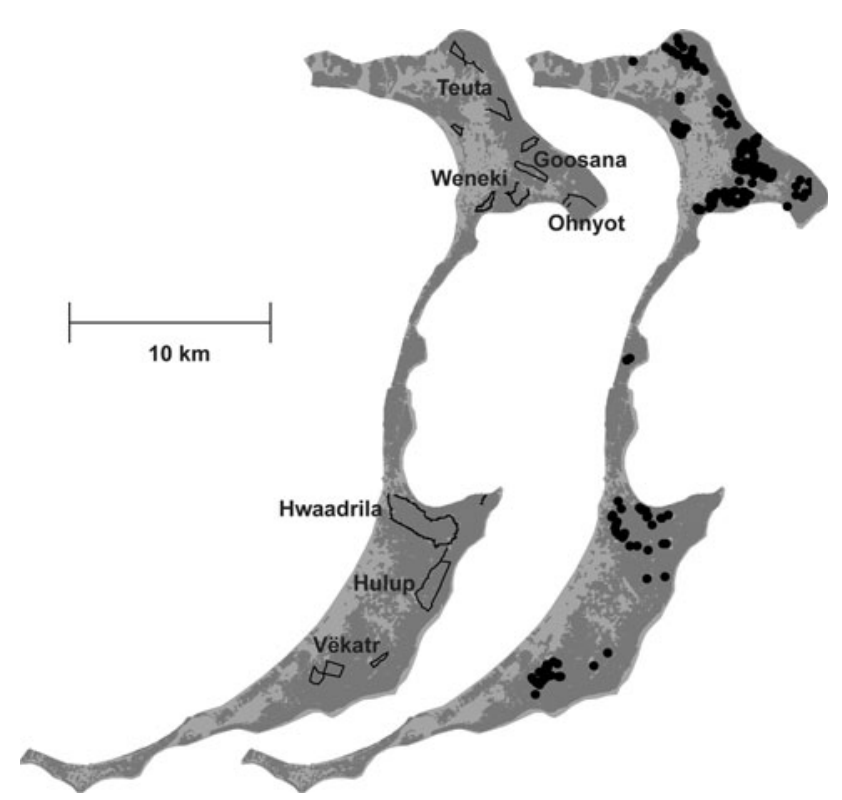

Fig. 1 Distribution of rainforest (dark grey), other vegetation types (light grey), transects (lines) and Ouvéa Parakeet (Eunymphicus uvaeensis) encounters during censuses and occasional observations from 1993 to 2009 (dots) on Ouvéa, Loyalty Islands, New Caledonia (locality names from IGN 1992) 
field. Since 2006, the number of employed guides has increased to nine. Employing local guides from as many villages as possible was essential for the ASPO conservation strategy, because nest poaching was formerly organised by each village. We believe that local guides, as accepted members of the local community, had a much higher impact on the attitudes of people than laws established by the government of Grande Terre. As nest takes were illegal, it is difficult to obtain detailed information on poaching rates before local guides were employed. However, we have no evidence of nest poaching occurring since at least 2000.

Ouvéa Parakeets use a limited number of habitats (Robinet et al. 1996): medium to high rainforest (canopy height $>6 \mathrm{~m}$ ), early stages of secondary forests, and active or abandoned gardens with papaya (Carica papaya) and other plants consumed by the bird. About $41.5 \mathrm{~km}^{2}$ of south Ouvéa, and $20 \mathrm{~km}^{2}$ of north Ouvéa are covered by suitable habitats (analyses based on digital versions of 1:10,000 scale maps of IGN 1992, Robinet et al. 1996).

From 1993 to 2009, we surveyed parakeet numbers on eight occasions, all in November-December (Table 1).
Transects were walked slowly (1-2 km/h), usually by three observers, who followed either a forest track or a compass bearing through forest. Transects were typically carried out from 0600 to 1100 and from 1500 to 1800 hours. We did not survey in strong wind or rain. Whenever possible, the same itineraries were used on each census. However, small orientation errors, caused by the absence of permanent tracks or marks, meant that some portions of the transects did not correspond exactly during each survey; therefore, the length was not always the same. There were eight transects in the north and five in the south repeated during each survey (Fig. 1).

From 1993 to 2000, we used the line transect method of Bibby et al. (1992), as described in detail by Robinet et al. (1996). We used two distance belts to estimate population density: up to $15 \mathrm{~m}$ perpendicular from the transect line, and beyond $15 \mathrm{~m}$. We chose the distance of $15 \mathrm{~m}$ to separate belts as we were confident that we were able to find all parakeets within this distance from the transect line. We divided transects into units of $500 \mathrm{~m}$, which allowed us to calculate the mean number of birds per $500 \mathrm{~m}$ (based on all birds seen), a density (using only encounters within the

Table 1 Number of Ouvéa Parakeets (Eunymphicus uvaeensis) recorded per $500 \mathrm{~m}$, dates and total length of transects in the north $(N)$, south $(S)$ and the entire island (weighted by surface of suitable habitat) of Ouvéa

\begin{tabular}{|c|c|c|c|c|c|c|}
\hline Year & Dates & Zone & $\begin{array}{l}\text { Length of } \\
\text { transects }(\mathrm{km})\end{array}$ & $\begin{array}{l}\text { Birds }(0-15 \mathrm{~m} \\
\text { from transect) }\end{array}$ & $\begin{array}{l}\text { Birds (16-60 m } \\
\text { from transects) }\end{array}$ & Birds $/ 500 \mathrm{~m}$ \\
\hline \multirow[t]{3}{*}{1993} & $28 / 11-06 / 12$ & $\mathrm{~N}$ & 35.9 & 29 & 19 & 0.67 \\
\hline & & $\mathrm{S}$ & 29.1 & 2 & 1 & 0.05 \\
\hline & & Ouvéa & & & & 0.26 \\
\hline \multirow[t]{3}{*}{1998} & $15-18 / 12$ & $\mathrm{~N}$ & 15.9 & 46 & 18 & 2.00 \\
\hline & & $\mathrm{S}$ & 9.9 & 3 & 0 & 0.15 \\
\hline & & Ouvéa & & & & 0.77 \\
\hline \multirow[t]{3}{*}{2000} & $28 / 11-01 / 12$ & $\mathrm{~N}$ & 22.8 & 30 & 6 & 0.80 \\
\hline & & $\mathrm{S}$ & 21.1 & 4 & 3 & 0.17 \\
\hline & & Ouvéa & & & & 0.38 \\
\hline \multirow[t]{3}{*}{2003} & 06-09/12 & $\mathrm{N}$ & 24.9 & 7 & 40 & 0.94 \\
\hline & & $\mathrm{S}$ & 27.8 & 11 & 18 & 0.52 \\
\hline & & Ouvéa & & & & 0.66 \\
\hline \multirow[t]{3}{*}{2004} & $29 / 11-03 / 12$ & $\mathrm{~N}$ & 25.7 & 18 & 30 & 0.93 \\
\hline & & $\mathrm{S}$ & 27.8 & 10 & 9 & 0.34 \\
\hline & & Ouvéa & & & & 0.54 \\
\hline \multirow[t]{3}{*}{2006} & $02-04 / 12$ & $\mathrm{~N}$ & 26.7 & 25 & 49 & 1.39 \\
\hline & & $\mathrm{S}$ & 27.0 & 9 & 28 & 1.37 \\
\hline & & Ouvéa & & & & 1.38 \\
\hline \multirow[t]{3}{*}{2008} & $06-10 / 12$ & $\mathrm{~N}$ & 25.6 & 37 & 62 & 1.93 \\
\hline & & $\mathrm{S}$ & 25.7 & 16 & 24 & 0.78 \\
\hline & & Ouvéa & & & & 1.16 \\
\hline \multirow[t]{3}{*}{2009} & $01-03 / 12$ & $\mathrm{~N}$ & 27.8 & 40 & 49 & 1.60 \\
\hline & & $\mathrm{S}$ & 26.3 & 18 & 12 & 0.57 \\
\hline & & Ouvéa & & & & 0.91 \\
\hline
\end{tabular}


inner $15 \mathrm{~m}$ belt), and an estimation of the population, as described in detail in Robinet et al. (1996).

Since 2003, we have estimated parakeet numbers by distance sampling (Buckland et al. 1993), and have therefore recorded the exact distance of each observation to the transect line. When parakeets were in a flock, we estimated the distance to the flock based on the average distance to each individual. We calculated parakeet numbers and confidence intervals with Distance 6.0 Release 2 (Thomas et al. 2009) and truncated any distances beyond $60 \mathrm{~m}$ from the transect line, which is proposed as standard for estimating parrot density in New Caledonia (A. Legault, J. Theuerkauf, S. Rouys et al., unpublished manuscript). We estimated parakeet numbers by multiplying the estimated densities with the area of suitable habitats on Ouvéa. In order to allow for statistical comparison among years and methods, we compared the number of parakeets per $500 \mathrm{~m}$ (up to a maximum distance of $60 \mathrm{~m}$ from the transect line). To check if there was an increase in parakeet numbers, we tested whether the slope variable of the regression model was significant. We tested five regression models (linear, quadratic, growth, exponential, logistic) with PASW Statistics 18 (SPSS) to find out which model best fitted the data (ranked by $F$ value). We aged parakeets in the field. Young parakeets (up to a few months old) are recognisable by a yellow bill and the absence of a crest. During surveys, we noted whenever we encountered Rainbow Lorikeets, Brown Goshawks or Little Fire Ants.

\section{Results}

The mean Ouvéa Parakeet density increased threefold from 10 (4-16) birds per $\mathrm{km}^{2}$ in 1993 to 34 (21-56) birds per $\mathrm{km}^{2}$ (95\% confidence interval) in 2009 (Fig. 2). Growth, logistic and exponential models best fitted the increase in the number of parakeets encountered per $500 \mathrm{~m}$ of transect per year (data in Table 1). $F$ and $P$ values of these three models were identical (entire island: $F=10.8, P=0.017$; south: $F=30.5, P=0.001$; north: $F=2.8, P=0.153$ ). The linear model was also significant for the entire island $(P=0.037)$ and the south $(P=0.050)$, whereas the quadratic model was not significant in any region.

Out of the 349 encounters with parakeets over the entire survey period, $40 \%$ were single birds, $43 \%$ were pairs and $17 \%$ were groups of three or more birds. In total, we aged 188 birds, including 146 in the north and 42 in the south. Of these, $19 \%$ (21\% in the north, $12 \%$ in the south) were juveniles.

We did not detect any change in the relative abundance of Brown Goshawks during the 16-year monitoring period (1-2 birds observed per day throughout the study). The Rainbow Lorikeet was rare and was never observed in the
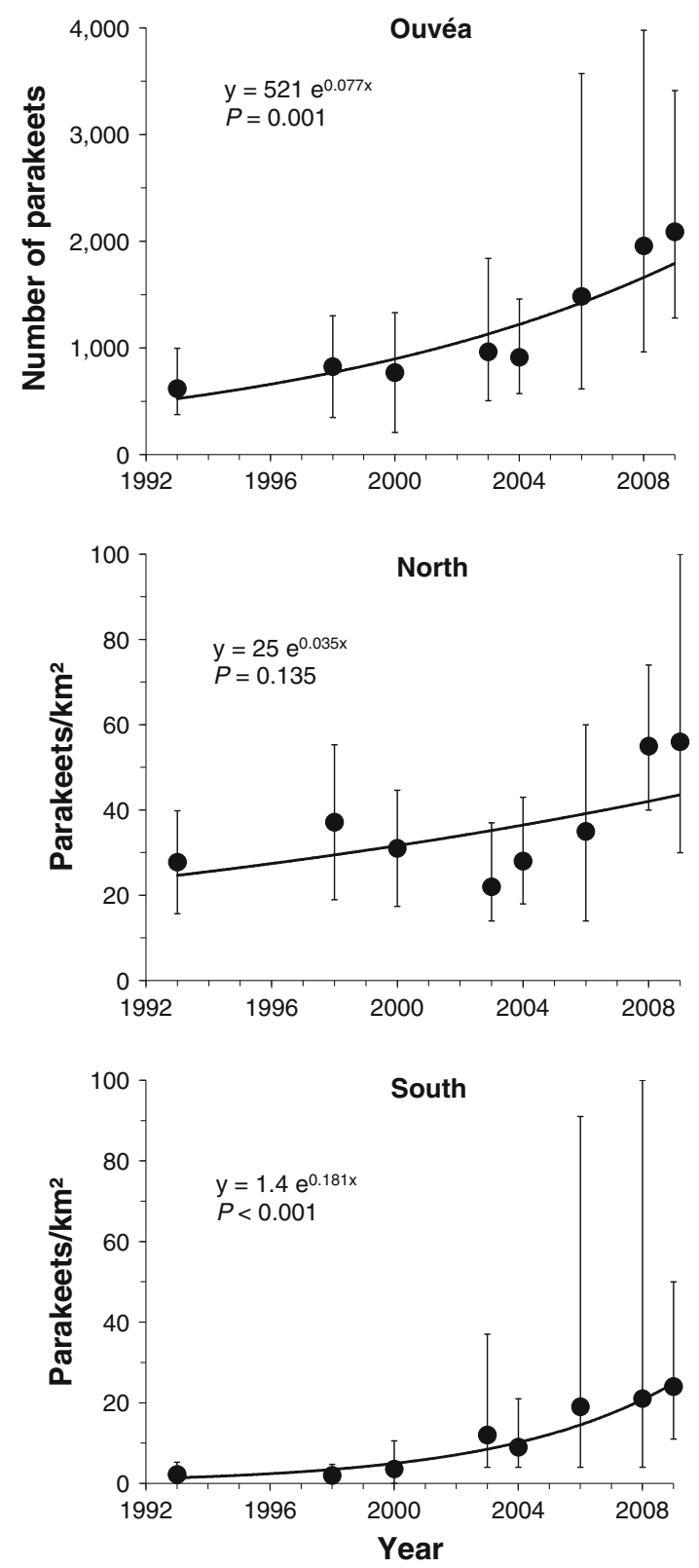

Fig. 2 Estimated parakeet numbers on Ouvéa and parakeet density (with 95\% confidence intervals) in the north and south with exponential regression lines $(x=$ years after 1993)

habitat used by the Ouvéa Parakeets. The Little Fire Ant was recorded on most of our transects in 1998-2003, but was a little less widespread from 2004 to 2009.

The financial investment for the conservation of the Ouvéa Parakeet (ASPO budget) was insignificant before 1998, but increased afterwards continuously due to the support of the Loyalty Islands administration (Fig. 3). Initially, the money was mainly spent on public awareness (organisation of meetings and publications), but later most of the money was spent for salaries of guides (recruitment of local personnel all over the island for field surveys) and stationary costs (office, phone, etc.). 


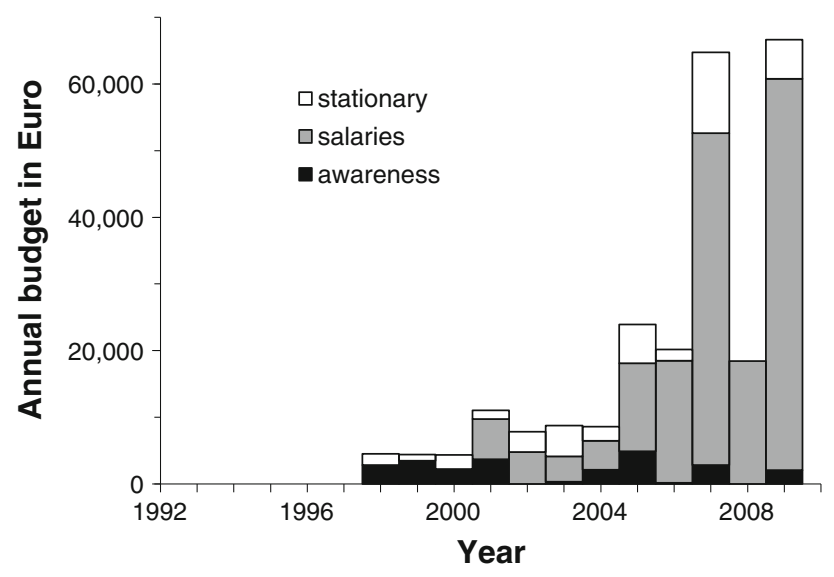

Fig. 3 Budget of the ASPO for public awareness, salaries and stationary costs in 1993-2009

\section{Discussion}

In 2009, we estimated a mean population density of 34 parakeets per $\mathrm{km}^{2}$ across Ouvéa. Parakeet density was highest in the north, where it reached 57 birds per $\mathrm{km}^{2}$ (see Fig. 2). These densities are about twice as high as the mean and maximum densities of Horned Parakeets observed on mainland New Caledonia (A. Legault, J. Theuerkauf, S. Rouys et al., unpublished manuscript). In the north, the population was relatively stable and high throughout the monitoring period. Most of the population increase has occurred in the south where the bird numbers were very low in 1993. As the percentage of young in the north was twice that in the south, it is likely that at least a part of the population increase in the south was caused by dispersal of birds from the productive northern subpopulation through the central isthmus of the island.

Robinet and Salas (1996) observed that Ouvéa Parakeets had a relatively high reproductive output, which we can confirm, as $19 \%$ of birds observed were fledglings. Ouvéa Parakeets had an annual fledging rate of $63 \%$, a clutch size of 2.9, and 1-2 broods per year (Robinet and Salas 1996), which is comparable to that of Horned Parakeets from the mainland of New Caledonia (Theuerkauf et al. 2009). Robinet et al. (1996) therefore suspected that the scarcity of tree cavities in mature trees was the limiting factor for Ouvéa Parakeet density. This could explain why the bird is absent or scarce in some forested parts of the island: the transects on Ohnyot in the north and Hulup in the south are in rainforest, but the trees are of medium size, and are probably unsuitable for nests. Furthermore, two trials to install artificial nests (50 wooden nests of two different sizes in 1994 and 35 PVC nests in 2005) in rainforests in the north of Ouvéa (Teuta, Weneki and Goossana) were unsuccessful, as birds did not use the nests. Parrots only use artificial nest boxes if they are suitable, even if they have to compete for nests (Brightsmith and Bravo 2006). Thus, we are unsure if the parakeet population in the high density areas was limited by the availability of suitable nest cavities. To contribute to the population increase, we suggest that additional artificial nest-cavities be provided in forested areas that lack mature trees and have low parakeet numbers.

The Ouvéa Parakeet population increased exponentially during the monitoring period, despite little or no change in the state of potential threats caused by Brown Goshawks, Rainbow Lorikeets or Little Fire Ants. We have no reason to believe that other potential threats, such as Pacific Boas, Pacific Rats (Rattus exulans) or Feral Cats decreased or increased in numbers. Honey Bees occupied 10-16\% of the known Ouvéa Parakeet nest-sites (ASPO 2003). The ASPO staff destroyed or removed 187 bee colonies during 2002-2008, although this did not result in a noticeable reduction of bee colonies. We therefore believe that the increase was mainly due to the prevention of poaching since 1993.

Nest poaching is a serious problem for parrot species worldwide (Wright et al. 2001, Pain et al. 2006). We think that the successful prevention of nest poaching on Ouvéa was not primarily facilitated by legal protection, which was established since 1956, but by community-based measures taken after the creation of the ASPO. The continuous presence of local guides effectively prevented nest poaching, and the increased financial support allowed awareness and conservation actions. Today, many people on Ouvéa appreciate the value of the bird, which has become the island emblem: the Ouvéa council has included a parakeet in its $\log$ o, and a monumental sculpture representing the bird was erected at the Ouvéa airport in 1999 as a reminder of the richness of the local biodiversity. This demonstrates that by remaining in the wild, the parakeet can be a natural resource providing income for those inhabiting an island where unemployment is high. Smuggling seems to have disappeared since the implementation of the awareness campaign and other ASPO actions.

We recommend continuing actions to raise awareness, implementing measures to prevent future introductions of potential predators (e.g. the Black Rat) and preserving all of the remnant rainforest, as proposed in the recovery plans (ASPO 2003; Anonymous 2004). We believe that it is also important to improve incomes and job opportunities for the inhabitants of Ouvéa, in order to prevent nest poaching and smuggling of the Ouvéa Parakeet in the long term. We conclude that Ouvéa Parakeet nest poaching has been eliminated because of the protection provided by local people, which is potentially due to the more reliable incomes offered through tourism than nest poaching. 


\section{Zusammenfassung}

Exponentieller Populationszuwachs des Ouvéa-Sittichs (Eunymphicus uvaeensis) nach selbst durchgeführten Schutzmaßnahmen der Inselbevölkerung gegen Nestwilderei

Der Ouvéa-Sittich (Eunymphicus uvaeensis), eine endemische Art der Loyalitätsinsel Ouvéa (Neukaledonien, Südwestpazifik), ist eine Feuchtwaldart, die Bäumhöhlen zum Nisten benötigt. Die Art ist bedroht durch Waldzerstörung, durch eingeführte Bienen, die mit den Sittichen um Nisthöhlen konkurrieren, durch die Entnahme von Jungvögeln aus den Nestern und potentiell durch eingeführte Prädatoren. Wir zeigen, dass trotz dieser Bedrohungen die Population der Ouvéa-Sittiche exponentiell von geschätzten 617 (274-996) Vögeln im Jahre 1993 auf 2.090 (1.280-3.413) Vögel im Jahre 2009 gewachsen ist (95\% Konfidenzintervall). Diesen Populationszuwachs erklären wir damit, dass die einheimische Bevölkerung die Schutzmaßnahmen selbst umsetzte, so dass die Entnahme der Jungvögel unterbunden werden konnte. Wir empfehlen diese Maßnahmen weiterzuführen, den verbliebenen Feuchtwald zu schützen und die Einführung von Ratten zu verhindern.

Acknowledgments This study was financed by the Province des Iles Loyauté (New Caledonia), the ASPO (New Caledonia), the Société Calédonienne d'Ornithologie (New Caledonia) and the British Birdwatching Fair (U.K.). J.T. was supported by the Loro Parque Fundación (Spain) and Fonds für bedrohte Papageien-Zoologische Gesellschaft für Arten- und Populationsschutz (Germany). We thank the members of the ASPO-S. Baoutuau, J.F. Chaouri, J.B. Dao, P. Dialla, V. Mindia, B. Tangopi, W. Wamo, L. Wéa, and A. Wétéwéa-for guiding us on their lands; T.C. Greene and R.G. Powlesland for advice; M.F. Barré, J.C. Birot, M. Boissenin, V. Chartendrault, F. Desmoulins, J. Spaggiari, and C. Vanhoye for their help during field work; and D. Brightsmith, G. Dutson, T.W.P. Friedl, A. Legault, T. Müller, J.M. Wunderle and anonymous reviewers for useful comments and corrections.

\section{References}

Anonymous (2004) Un exemple de gestion concertée avec les coutumiers: la Perruche d'Ouvéa. Bilan du second séminaire. 11-14. Le nouveau plan de sauvegarde de la Perruche d'Ouvéa (2004-2008). Les Cahiers de l'Agriculture et de l'Environnement. Iles Loyauté, $\mathrm{N}^{\circ} 5$

ASPO (2003) Second séminaire pour la conservation de la Perruche d'Ouvéa. Bilan du plan de sauvegarde 1997-2002. Elaboration du plan de sauvegarde 2003-2008

Berlioz J (1945) Les Psittacidés de la Nouvelle-Calédonie et des établissements français d'Océanie. Oiseau Rev Fr Ornithol 15:1-9

Bibby CJ, Burgess ND, Hill DA (1992) Bird census techniques. Academic, London

BirdLife International (2009) Species factsheet: Eunymphicus uvaeensis. (http://www.birdlife.org) downloaded on 9 August 2009
Boon WM, Robinet O, Rawlence N, Bretagnolle V, Norman JA, Christidis L, Chambers GK (2008) Morphological, behavioural and genetic differentiation within the horned parakeet (Eunymphicus cornutus) and its affinities to Cyanoramphus and Prosopeia. Emu 108:251-260

Brightsmith D, Bravo A (2006) Ecology and management of nesting blue-and-yellow macaws (Ara ararauna) in Mauritia palm swamps. Biodiv Conserv 15:4271-4287

Bruce MD (1978) L'avifaune de Lifou (Archipel des Loyauté). Alauda 46:295-308

Buckland ST, Anderson DR, Burnham KP, Laake JL (1993) Distance sampling: estimating abundance of biological populations. Chapman \& Hall, London

Collar NJ, Crosby MJ, Stattersfield AJ (1994) Birds to watch 2. The world list of threatened birds. Bird life conservation series $\mathrm{N}^{\circ} 4$. BirdLife International, Cambridge UK

Hahn P (1993) Anmerkungen zur Situation des Hornsittichs Eunymphicus cornutus auf Neukaledonien und Ouvéa. Papageien 6:181-189

Hannecart F (1988) Les oiseaux menacés de la Nouvelle-Calédonie et des îles proches. In: Thibault JC, Guyot I (eds) Livre Rouge des Oiseaux menacés des Régions Françaises d'Outre-Mer. CIPO Monographies $\mathrm{N}^{\circ} 5$, Cambridge, UK

IGN (1992) Ouvéa. Carte topographique. Institut Géographique National, Paris

Jourdan H (1997) Threats on Pacific Islands: the spread of the tramp ant Wasmannia auropunctata (Hymenoptera: Formicidae). Pac Conserv Biol 3:61-64

Juniper T, Parr M (1998) Parrots - a guide to parrots of the world. Yale University Press, New Haven, London

King W (1981) Endangered birds of the world. The ICBP red data book. Smithsonian Institution Press, Washington, DC

Lambert F, Wirth R, Ulysses SS, Thomsen JB, Ellis-Joseph S (1992) Parrots: an action plan for their conservation 1993-1998. BirdLife International-IUCN, Cambridge

Pain DJ, Martins TLF, Boussekey M, Diaz SH, Downs CT, Ekstrom JMM, Garnett S, Gilardi JD, McNiven D, Primot P, Rouys S, Saoumoé M, Symes CT, Tamungang SA, Theuerkauf J, Villafuerte D, Verfailles L, Widmann P, Widmann ID (2006) Impact of protection on nest take and nesting success of parrots in Africa, Asia and Australasia. Anim Conserv 9:322-330

Robinet OL (1997) Ecology and conservation of the Ouvea parakeet Eunymphicus cornutus uvaeensis (Loyalty Islands, New Caledonia). $\mathrm{PhD}$ thesis, University of Auckland

Robinet O, Salas M (1996) Absence of ship rat Rattus rattus, and Norway rat Rattus norvegicus, on Ouvea (Loyalty Islands, New Caledonia): consequences for conservation. Pac Conserv Biol 2:390-397

Robinet O, Beugnet F, Dulieu D, Chardonnet P (1995) The Ouvea parakeet-state of knowledge and conservation status. Oryx $29: 143-150$

Robinet O, Barré N, Salas M (1996) Population estimate for the Ouvea parakeet Eunymphicus cornutus uvaeensis: its present range and implications for conservation. Emu 98:151-157

Sarasin F (1913) Die Vögel Neu-Caledoniens und der Loyalty-Inseln. In: Sarasin F, Roux J (eds) Nova Caledonia: Forschungen in Neu-Caledonien und auf den Loyalty-Inseln-Recherche scientifiques en Nouvelle Calédonie et aux Iles Loyalty. A. Zoologie 1 (1). C.W. Kreidels Verlag, Wiesbaden, pp 1-78

Sherley G (2000) South Pacific regional bird conservation programme plan for action. Proceedings of the Melanesia and Nauru Avifauna conservation workshop, Nadi, Fiji, 5-10 March, 2000. SPREP-BirdLife International

Spaggiari J, Chartendrault V, Barré N (2007) Zones importantes pour la conservation des oiseaux de Nouvelle-Calédonie. Société 
Calédonienne d'Ornithologie and BirdLife International, Nouméa, Nouvelle-Calédonie

Taylor B (2005) A report on the prevalence and population growth of Apis mellifera feral colonies on Ouvea and management strategies to reduce the impact on the Ouvea parakeet. AgriQuality report, New Zealand

Theuerkauf J, Rouys S, Mériot JM, Gula R, Kuehn R (2009) Cooperative breeding, mate guarding, and nest sharing in two parrot species of New Caledonia. J Ornithol 150:791-797

Thomas L, Laake JL, Rexstad E, Strindberg S, Marques FFC, Buckland ST, Borchers DL, Anderson DR, Burnham KP, Burt ML, Hedley SL, Pollard JH, Bishop JRB, Marques TA (2009) Distance 6.0 Release 2. Research Unit for wildlife population assessment, University of St. Andrews, UK. (http://www.ruwpa. st-and.ac.uk/distance/)

UNEP-WCMC (2009) UNEP-WCMC species database: CITES-listed species. (http://www.unep-wcmc.org/isdb/CITES/) downloaded on 19 April 2009

Wright TF, Toft CA, Enkerlin-Hoeflich E, Gonzales-Elizondo J, Albornoz M, Rodriguez-Ferraro A, Rojas-Suarez F, Sanz V, Trujillo A, Beissinger SR, Berovides AV, Galvez AX, Brice AT, Joyner K, Eberhard J, Gilardi J, Koenig SE, Stoleson S, Martuscelli P, Meyers JM, Renton K, Rodriguez AM, SosaAsanza AC, Vilella FJ, Wiley JW (2001) Nest poaching in neotropical parrots. Conserv Biol 15:710-720 